a defect may be important in some isolated instances of cot death. In the meanwhile I would suggest that Dr. Englander's theory be added to the rest of many dozens of nonproven theories put forward to explain "cot death." -I am, etc.,

Department of Pathology,

JOHN L. EMERY

Children's Hospital,
Sheffield 10

\section{Latex Agglutination Test for Australia} Antigen

SIR,-We were interested to see Mr. J. M. Leach and Mr. B. J. Ruck's paper (4 December, p. 597) in which they state that the latex agglutination test for the detection of Australia antigen was both rapid and reliable. Presumably this paper was submitted before a recent discussion on this technique organized by Pfizers Ltd. was held (22 November 1971). Those present, many of whom had tried the latex agglutination test, agreed that it had considerable potential. However, it was generally felt that a variable but significant number of false positive results made its use for diagnostic purposes premature and that further efforts on the one hand to increase its sensitivity and reliability and to improve its safety in handling on the other were required. We therefore hope that this technique will not be generally employed until such improvements have been made and further trials conducted.-We are, etc.,

J. E. Banatvala JENNIFER M. BEST

Department of Virology, St. Thomas's Hospital and Medical School

JUNE D. AlmeidA

Royal Postgraduate Medical School,

London W.12

D. M. S. DANE

Middlesex Hospital,

London $W .1$

\section{Clinical Tutors and Medical Centres}

SIR,-The leading article "Clinical Tutors and Medical Centres" (4 December, p. 572) perpetuates the traditional assumption made by the profession that pharmaceutical companies are unable to transmit or present balanced objective information, a point of view which was more easily justified 20 years ago than in the case in 1971 .

In my experience the many executives responsible for the elaboration, presentation, and vetting of information destined for the medical and allied professions are undertaking their duties with an increasing sense of social and professional responsibility; moreover, with a genuine desire to ensure that all relevant information is placed before the prescriber in a manner which enables him to exercise his intellectual judgment in deciding the role, if any, which any medication may have to play in his armamentarium.

In my view the pharmaceutical company cannot properly fulfil its obligation to disseminate that information unless it is given free and unfettered access to the platforms of the postgraduate centres and the editorial columns of the medical press. The clinical tutor and the journal editors should, of course, be equally free to ensure that all and any material so conveyed or published is accompanied by an independent and expert critique.

It is only in this way, through construc- tive and critical exchanges, that the profession can be assured if they will receive the information service it deserves.-I am, etc.,

R. LEVIN

Maidenhead, Berk Marketing Director,
Syntex Pharmaceuticals Ltd.

\section{Simpson and Hans Andersen}

SIR,-In the article entitled "Three Letters by Sir James Young Simpson" the third letter contained an invitation to dinner at Dr. Simpson's home to Dr. John Moir in honour of Hans Christian Andersen, during the latter's visit to Scotland in the summer of 1847.

Making my own investigations here in Copenhagen, I found a reference to this event by $\mathrm{H}$. C. Andersen in his memoirs Mit Livs Eventyr ${ }^{2}$ published in Copenhagen in 1855 (translated into English under the title of The Fairy Tale of My Life $e^{3}$.

Apparently the dinner took place on 17 August, and Andersen writes: "I came in contact with several famous people in social life ... at the home of the excellent $\mathrm{Dr}$. Simpson ... 'The Danish Walter Scott' was the name of honour with which many people honoured me, unworthy though I was. Mrs. Crowe, the authoress, presented me with her novel Susan Hopley which has also been translated into Danish. We met at the home of Dr. Simpson, and in the large circle which was gathered there several experiments were made with breathing in ether. I thought it distasteful, especially to see ladies in this dreamy intoxication; they laughed with open, lifeless eyes; there was something unpleasant about it, and I said so, recognizing at the same time that it was a wonderful and blessed invention to use in painful operations, but not to play with; it was wrong to do it; it was almost like tempting God; a worthy old gentleman took my part and said the same; by asserting what I did I seemed to have won his heart."

Andersen also made the following entry into his diary: "August the 17th: Dinner at Dr. Simpson, where Mrs. Crowe and another poet drank ether. I had the feeling of being among two insane who laughed with open eyes; there was something frightening in this; I found it outstanding for operation, but not to be used to tempt God,"

It is common knowledge that Simpson in November 1847 first used chloroform in his living room, but it may not be so well known that he used ether inhalation for entertaining his guests.

H. C. Andersen's host on this visit to Scotland was Carl Joachim Hambro (180777). His wife, Caroline Marie (1810-52), was sick and for this reason spent some recreation time in Scotland, and happened to be one of Simpson's patients. This is how Andersen met Simpson. The Hambro family ${ }^{4}$ were of Danish origin, and Andersen must have met them or at least heard of them in Copenhagen, where they were well known. It was together with Joseph Hambro (1770-1848), whom Andersen had met in London, that he went to Scotland, leaving London on 10 August.

Joseph Hambro had started as a street vendor in Copenhagen, selling laces and other small merchandise; subsequently he acquired his own milliner's shop, expanded, made trade contacts in the Danish islands in the West Indies-the Virgin Islandsand established a banking firm. In 1821 he negotiated a loan for Denmark in England, and as a result was elected a Hofraad (court advisor) by King Frederik VI. In time Carl Joachim became a partner in his father's firm, but emigrated to England in 1839, where his father followed him in 1840, possibly because, as a Jew, he could not be elected to the Standerforsamlingen (the House of Representatives). In London Carl Joachim opened a banking firm, which, thanks to his father's connexions, grew fast. In 1850, at the end of a three-year war between Germany and Denmark, Carl Joachim procured another English loan for Denmark, and was duly elected a baron in 1851 by King Frederik VII for services rendered.

Finally, I found mention of Dr. John Moir in the Danish Medical fournal of 25 March 1847. A Danish medical doctor, H. C. Saxtorph (1813-75), having studied in Edinburgh in 1843 and apparently well known to Simpson, published a report $^{5}$ communicated to him by Simpson on the latter's first experiences with the use of ether anaesthesia in six delivery cases. The first of these were stated to have been performed on 19 January 1947; in another case, on 3 February, Dr. John Moir is mentioned as having performed a forceps delivery.-I am, etc.,

Ole Secher

Rigshospitalet

Copenhagen, Denmark

Gaskell, E., British Medical fournal, 1970, 2,

414. . E., Briltsh Medical fournal, 1970, 2, Gyldendal, 1951 .

3 Andersen, H. C.; The Fairy Tale of My Life. Copenhagen, Arnold Busck, 1954 . Dahl, S., and Engelstoft, P. Dansk biografisk Händleksikon.. Copenhagen, Gyldendal, 1920.
Saxtorph, H. C., Ugeskrift for Lager, 1847, 2.R. B.6, 264 .

\section{Specificity of Exercise in Exercise-induced} Asthma

SIR,-We were very interested in the paper by Dr. K. D. Fitch and Mr. A. R. Morton (4 December, p. 577) on the effects of different types of exercise in asthma. Their results are similar in many respects to those which we published a few months ago on the effects of cycling, treadmill running, and free range running. ${ }^{1}$ However, we standardized the exercise by monitoring oxygen consumption as well as heart rate and other ventilatory parameters, and were thus able to control the work being done more accurately than by measuring heart rate alone. Subsequently, we have also studied the response to swimming and arm exercise using similar methods.

We found running to be a more potent stimulus to bronchoconstriction than cycling or the other forms of exercise. Free range running was even more potent than treadmill running. The relatively small difference between treadmill running and cycling found by Dr. Fitch and Mr. Morton may have been due to the matching of work based solely on pulse, or to the fact that some patients received drugs known to reduce exercise-induced bronchoconstriction. ${ }^{2}$ With regard to the mechanisms of exerciseinduced asthma we have measured levels of IgE before and after exercise in six subjects and they showed variable changes. We have also carried out detailed studies of blood 
gases, lactate metabolism, and acid-base balance during and after exercise, and some of the results are to be published shortly. Basically we found that none of these factors could explain the origin of exercise-induced asthma or the difference with different forms of exercise. Likewise, we have studied lung volumes and mechanical properties and found that they reflect rather than cause the asthma.

Finally, we would like to repeat our earlier suggestion that the mechanism of exercise-induced asthma and the difference between the severe constriction due to running compared with the virtual absence during swimming may reflect neuromuscular differences in the types of exercise. For this reason, we are now proposing to study the effect of whole body vibration at a level similar to that which occurs during running in patients with asthma.-We are, etc.

\section{SANDRA D. ANDERSON}

M. Silverman

E. TAI

S. GODFREY

Department of Paediatrics,

Institute of Diseases of the Chest.

London S.W. 3

1 Anderson, S. D., Connolly, N. M., and Godfrey, S., Thorax, 1971, 26, 396 . Connolly, N. M., and Godfrey, S., fournal of

\section{Prepubertal Vaginal Examination}

SIR,-It is occasionally necessary to perform a pelvic examination on a prepubertal girl. The usual indication for this is when it is suspected that a nonopaque foreign body has been inserted into the vagina. Pelvic examination is usually performed with an auriscope or a nasal speculum. Both these methods do not always give an adequate view of the whole vagina and may tear the hymen.

Recently I have visualized the vagina using a laparoscope with a fibre optic light source. This can be inserted through the intact hymen without trauma. The whole of the vagina and cervix may be examined in detail. If the hymeneal orifice is small the Stortz instrument is more valuable than the Wolf laparoscope because of its narrower bore. Either the $180^{\circ}$ lens or the $130^{\circ}$ lens can be used, but the $180^{\circ}$ lens is probably best to exclude the presence of a foreign body.-I am, etc.,

Maternity Unit,

Watford General Hospital,

Watford, Herts

\section{Intravenous Glucagon}

SIR,-Glucagon is a biological product which for many years has been given by parenteral injection in the management of severe hypoglycaemia occurring in patients with diabetes mellitus. In this context glucagon is safe and effective. More recently, in certain experimental studies, investigators have been administering glucagon by intravenous infusion or repeated bolus injections in the management of certain cardiovascular conditions (28 August, p. 524) and in the treatment of acute pancreatitis (22 May, p. 440). Recent animal studies in the Lilly laboratories have revealed findings that may be of concern regarding continuous infusion of high concentrations of glucagon.

Dogs were infused intravenously with glucagon dissolved in $5 \%(w / v)$ dextrose solution continuously for periods of five days to four weeks. The amounts given were four to ten times the human dose for cardiac indications. (This we have taken as $4 \mathrm{mg} / \mathrm{hr}$ in a $70 \mathrm{~kg}$ man.) At the completion of the studies all tissues were found to be normal except the lungs. Several small pulmonary arteries contained small emboli (100-400 microns in diameter) of hyaline material. Material was birefringent when examined under polarized light, as are gels in vitro when glucagon solutions are subjected to optimal conditions for gel formation. The emboli had no clinically evident adverse effect on pulmonary function.

On the basis of these studies we feel that the investigational use of glucagon by intravenous infusion or by repeated intravenous injection should be curtailed until further studies elucidate this problem.-I am, etc.,

W. I. H. SHEDDEN Lilly Industries Ltd.

\section{European Pharmacopoeia}

SIR,-YYour note about the European Pharmacopoeia (Supplement, 11 December, p. 69) says that orders should be sent to the French publishers. In fact the distribution rights of the European Pharmacopoeia for most of the world outside continental Europe are held by The Pharmaceutical Press, 17 Bloomsbury Square, London WC1A 2NN Copies can be ordered either direct from The Pharmaceutical Press or through any medical bookseller. The price of each of the two volumes so far published is $£ 10$ post free.-I am, etc. The Pharmaceutical Press,
London W.C.1

Brian O'Malley

\section{Points from Letters}

\section{Acknowledgement for Help}

DR. M. H. Hughes (Public Health Laboratory, Royal Hampshire County Council, Winchester) writes: Dr. M. D. Hellier and others (13 November, p. 404) have reported an unusua and interesting case. Their report was based almost entirely on laboratory work. The colleagues who provided the reports on light and electronmicroscopial studies which form the
second half of the paper are thanked. The colsecond half of the paper are thanked. The col-
leagues, if any, who provided the serological reports on which the whole paper rested were not mentioned, nor was the source of the biochemical and haematological information revealed. ...

** We showed Dr. Hughes's comment to Dr. Hellier who replies as follows: "Dr. Hughes correctly points out our failure to acknowledge some of the help we obviously received in preparing our report, with particular reference to the serological results. These results were certainly important in confirming the clinical diagnosis of syphilis and we accept this point. We were most grateful to the Southampton Laboratory and the Venereal Disease Reference Laboratory for their results. However, in a brief, single case report a limit has to be made to the number and length of the acknowledgements. It is somewhat arbitrary and therefore difficult to know just where to draw this line. In any clinical case many individuals and departments are inevitably involved. ..."

\section{Bring Out Your Dead!}

SIR,-As a district medical officer of health I have accepted an increasing isolation from the health services as a part of a gradual process leading up to our forthcoming demise. It no longer comes as a surprise to find that the district medical officer of health is often one of the last persons to hear of developments in the health services in his area. Nevertheless it came as a very profound shock indeed to read in the Registrar General's Quarterly Return (quarter ended 30 June, 1971) $)^{1}$ that during 1970 there had been 209 deaths from plague in England and Wales.-I am, etc.,

East Sussex United Districts,

JoHN L. CotTon

East Sussex U
Lewes, Sussex 1 Registrar General's Quarterly Return for England
and Wales. London, H.M.S.O., 1971.

\section{Review Body Report}

SIR,-The pool by any other name stinks just as bad to me. I have suspected for some time that the deliberations of the Review Body were really based on a pool conception but this Review Body has come out quite honestly about it. They talk, of course, about the "average income of the general practitioner," but this multiplied by the number of practitioners brings you back to the pool. If more work is done and it is found that the average income is thereby more than it was estimated to be, this fact will be taken into account at the next review and the rate of remuneration cut.

Similarly it is now quite obvious that what was supposed to be extra money for incentives to go into group practice centres is in fact simply redistribution money.-I am, etc.,

Risca, Mon

MichaEL WADE

We would like to have been able to acknowledge all. For reasons that must surely be apparent this was not possib'e.-ED., B.M.f.

Breast-milk Jaundice and Oral Contraceptives

Drs. B. S. B. WOOD and Y. K. Wong (The Children's Hospital, Ladywood, Birmingham) write: We agree with Professor G. H. Lathe (4 December, p. 626) that we perhaps should have used the term "idiopathic jaundice" rather than "breast-milk jaundice" in our title. We have investigated the incidence of jaundice in bottle-fed infants and found it over all to be much lower than in the breast-fed-that is, around $15 \%$-and also that this incidence is the same whether the mothers had oral contraceptives or not.

\section{Pensions and the Abatement Rule}

Dr. A. S. Pearson (Sutton Coldfield, Warwicks) writes: I agree with Dr. E. M. Sandford (4 December, p. 627) .... I am not allowed to earn more than I did in 1963. If I do the extra money that $I$ receive from the N.H.S. is deducted from my pension. The most that I can earn is $£ 602$ per quarter, and when one considers the increased remuneration that general practitioners now get as compared with my salary in 1963, it is ludicrous. There is no provision made for increased cost of living, which since 1963 must be considerable. ... 